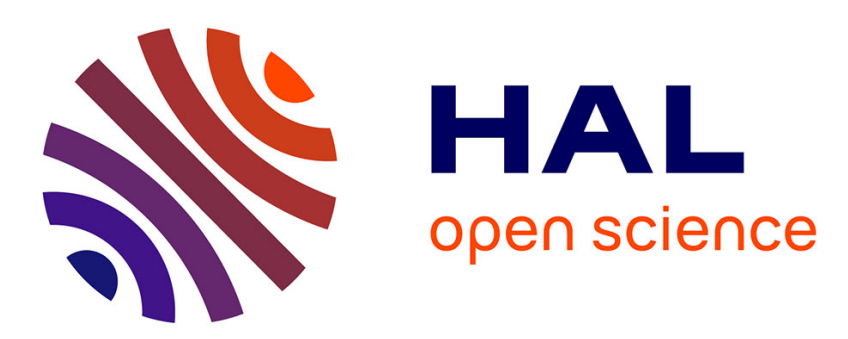

\title{
Market structure, financial intermediation and riskiness of banks:Evidence from Asia Pacific
}

Wahyoe Soedarmono, Amine Tarazi

\section{To cite this version:}

Wahyoe Soedarmono, Amine Tarazi. Market structure, financial intermediation and riskiness of banks:Evidence from Asia Pacific. 2014. hal-00947575

\section{HAL Id: hal-00947575 \\ https://hal-unilim.archives-ouvertes.fr/hal-00947575}

Preprint submitted on 17 Feb 2014

HAL is a multi-disciplinary open access archive for the deposit and dissemination of scientific research documents, whether they are published or not. The documents may come from teaching and research institutions in France or abroad, or from public or private research centers.
L'archive ouverte pluridisciplinaire HAL, est destinée au dépôt et à la diffusion de documents scientifiques de niveau recherche, publiés ou non, émanant des établissements d'enseignement et de recherche français ou étrangers, des laboratoires publics ou privés. 


\title{
Market structure, financial intermediation and riskiness of banks: Evidence from Asia Pacific
}

\author{
Wahyoe Soedarmono ${ }^{1}$ \\ Universitas Siswa Bangsa Internasional, Faculty of Business (Sampoerna School of \\ Business), Mulia Business Park Building D, Jl. MT. Haryono Kav. 58-60, \\ Jakarta 12780, Indonesia \\ Amine Tarazi \\ Université de Limoges, LAPE, 5 rue Félix Eboué BP3127, 87000 Limoges, France
}

\begin{abstract}
From a sample of commercial banks in Asia Pacific over the 1994-2009 period, this study highlights that banks in less competitive markets exhibit lower loan growth and higher instability. Such instability is further followed by a decline in deposit growth, suggesting that Asian banks are also subject to indirect market discipline mechanisms through bank market structure. This study therefore sheds light on the importance of enhancing bank competition to overcome bank risk and strengthen financial intermediation. This study also advocates greater reliance on market discipline to promote bank stability.
\end{abstract}

Keywords: Bank competition, loan growth, risk, market discipline, Asia Pacific JEL Classification: G21, G28

\footnotetext{
${ }^{1}$ Corresponding author. Tel.: +62 217942340

Email: wahyoe.soedarmono@ssb.ac.id (W. Soedarmono), amine.tarazi@unilim.fr (A. Tarazi)
} 


\section{Introduction}

In the wake of the global financial crisis of 2008 that has resulted in a cyclical downturn around the world, bank regulators are concerned with two major conflicting objectives. These include boosting financial intermediation that spurs economic growth or enhancing bank stability that may reduce banks' incentive to grant new loans. Meanwhile, some studies argue that banks in competitive markets tend to behave imprudently by taking too much risk due to a decline in their charter value as a selfdisciplining factor. However, it is also admitted that higher bank competition may enhance bank efficiency and reduce intermediation costs which in turn contribute to enhance economic growth (e.g. Brissimis et al., 2008; Demirgüç-Kunt et al, 2004; Fernandez et al, 2010).

In the meantime, to our best knowledge, there is no study that examines the implication of bank market structure on bank stability and financial intermediation simultaneously. Accordingly, financial stability and economic growth are often considered as two separate dimensions. As a matter of fact, bank stability plays an important role in economic development because higher bank riskiness can deteriorate banks' ability to grant loans, for example when losses are too important and lead to bank capital shortfalls. This problem is often referred to as "capital crunch" (e.g. Bernanke and Lown, 1991; Peek and Rosengren, 1995). Given that bank stability and financial intermediation are interrelated, this paper examines how bank competition affects both lending behaviour and stability in banking.

In this paper, we focus on commercial banks in Asia Pacific for several reasons.

First, the banking sector remains a major source of financing for the real sector in Asia Pacific (Adams, 2008). Second, substantial consolidations in the banking industry also occurred in Asia Pacific after the 1997 Asian crisis. Specifically, bank consolidations have grown significantly reaching 25\% per year as of 2003 (Santoso, 2009; Soedarmono et al., 2013). In addition, foreign direct investment (FDI) in banking also has increased from US\$ 2.5 billion over the 1991-1995 period to US\$ 67.5 billion over the 2001-2005 period and hence, Asian countries have become the second largest recipient of FDI in banking after Latin American countries (Domanski, 2005; Moshirian, 2008; Soedarmono et al., 2013). These financial landscape changes in Asia Pacific are more likely to affect 
bank market structure which can in turn alter the behavior of banks in terms of lending activities and risk taking.

For such reasons, focusing on Asia Pacific countries is particularly relevant to study the implication of bank competition on both bank stability and financial intermediation. To assess these issues, we retrieve a sample of commercial banks from 12 countries in Asia Pacific that have been affected by the 1997 crisis. These countries consist of Indonesia, Malaysia, South Korea and Thailand that have been severely affected by the 1997 crisis; as well as India, Pakistan, Philippines, Sri Lanka, China, Hong Kong, Taiwan and Vietnam that were less affected. This study covers the 19942009 period and emphasizes on the use of dynamic panel data techniques.

Our empirical findings show that higher bank competition strengthens both bank loan growth and stability. Furthermore, we also embrace discussions on the role of market discipline, since Shaeck and Cihak (2007) document that market discipline is likely to play a role in banks in competitive markets. In other words, competing banks tend to behave prudently by holding higher capital ratios to gain competitive advantage.

For a similar reason, in order to gain competitive advantage, banks in competitive markets can also be more transparent that those in less competitive markets. Hence, higher bank transparency facilitates ex-post market discipline by bank depositors whenever bank risk increases via changes in the market structure of banks. Specifically, our empirical results show that higher market power in banking increases bank risk, while banks in less competitive markets also experience lower deposit growth as a negative reaction of bank depositors. Such findings are consistent with the effectiveness of market discipline mechanisms in commercial banks in Asia Pacific.

The rest of this paper is structured as follows. Aside from highlighting our research contribution, Section 2 describes prior literature on the bank competitionstability nexus, as well as the bank competition-growth nexus. Section 3 presents our data, variables of interest and econometric models. Section 4 discuses our empirical findings and provides some robustness checks, while Section 5 concludes the paper. 


\section{Related literature and research contribution}

Bank market structure plays an important role in affecting bank stability and financial intermediation. However, the impact of bank market structure on bank stability and financial intermediation remains an open research area. With regards to the link between bank market structure and stability, two major hypotheses have emerged in the literature, i.e. the "charter value hypothesis" and the "competition-stability hypothesis". Regarding the impact of bank market structure on economic development, there are also two conflicting hypotheses: the "perfect information hypothesis" and the "asymmetric information hypothesis".

The charter value hypothesis argues that bank charter value is a self-disciplining factor that prevents banks from behaving imprudently and thus, higher bank competition eroding bank charter value can contribute to higher instability due to higher bank risk taking. Keeley (1990) documents that after financial liberalization in the nineties, US banks exhibited a decline in their charter value which in turn increased bank risk. Similarly, Demsetz et al. (1996) document that US banks with higher charter value tend to have better asset quality. Levy-Yeyati and Micco (2007) also support the charter value hypothesis in the case of Latin America. Beck et al. (2006) also examine the effect of bank concentration on the probability of banking crises in 69 countries during the 19801997 period. Their findings show that the probability of banking crises in countries with a concentrated banking system is lower than in countries with a competitive banking system. More recently, Ariss (2010) has focused on the case of developing countries and supports the charter value hypothesis.

In contrast, recent theoretical and empirical studies demonstrate that higher bank competition has a stabilizing effect when asymmetric information in loan markets is taken into consideration (Boyd and De Nicolo, 2005; Boyd et al, 2006). This is often referred to as the competition-stability hypothesis. As bank market power increases, banks can be riskier due to higher interest rate on loans. This is because the presence of asymmetric information in loan markets exacerbates entrepreneurial moral hazard to undertake risky projects to offset higher interest rate charged by banks with higher market power. Higher borrowers' risk can in turn negatively affect bank stability through a risk-shifting mechanism (Stiglitz and Weiss, 1981). In the case of European banks, 
Udhe and Heimeshoff (2009) support the competition-stability hypothesis through the link between bank concentration and several risk measures. Liu et al (2012) also find the similar results for Southeast Asian banks in which higher bank competition derived from the Panzar-Rosse approach is not associated with higher bank risk taking. As well, Soedarmono et al (2013) indicate that higher market power in Asian banking is associated with higher bank moral hazard, although banks hold a higher capital ratio. This finding is however reversed during the 1997 crisis period indicating that market power is necessary to prevent an increase in bank default risk in times of crisis.

While the link between bank competition and financial stability remains inconclusive, a related important issue is how bank competition affects financial intermediation and economic growth. On the one hand, the perfect information hypothesis argues that higher bank competition leads to higher economic growth because banks with higher market power tend to charge higher loan prices which may in turn preclude financial intermediation activities (Black and Strahan, 2002; Degryse and Ongena, 2005; Cetorelli and Gamberra, 2001). On the other hand, the asymmetric information hypothesis states that in the presence of asymmetric information, banks with higher charter value can erode asymmetric information by investing in relationship lending activities. Relationship lending can reduce firms' financing constraints, spur loan availability and enhance economic growth (Petersen and Rajan, 1994, 1995; Berlin and Mester, 1998).

Building on these previous studies, a potential trade-off between bank stability and financial intermediation can occur along with changes in bank market structure. Higher bank competition is indeed expected to boost loan growth because banks in more competitive markets tend to misprice their loan interest rates in expanding intermediation activities (Ogura, 2006). However, Foos et al (2010) provide evidence in which higher loan growth can lead to higher bank risk. In this paper we attempt to contribute to the ongoing debate regarding the impact of bank market structure on both bank stability and financial intermediation proxied by bank loan growth. Our paper extends the literature in several directions. First, a large number of studies rely on bank concentration or Herfindahl index measures to assess the degree of bank competition, while our present study employs the non-structural measure of bank competition derived from the new 
industrial organization approach following Soedarmono et al. (2011; 2013). Second, prior studies focus on the immediate impact of bank market structure, while this study also explores whether today's bank risk, and loan growth is determined by last year's bank market structure. Third, we extend the competition-stability-growth nexus by examining whether bank market structure affects depositors' reaction to bank risk and hence, we embrace issues on the role of market discipline exerted by bank depositors.

As a matter of fact, the association between bank competition and market discipline cannot be separated. Schaeck and Cihak (2007) emphasize that banks in competitive markets tend to behave prudently due to the presence of "peer market discipline" that induces competing banks to hold more capital to gain competitive advantages. Similarly, banks in competitive markets can be more motivated than those in concentrated market to strengthen information transparency for gaining further competitive advantages. Eventually, competitive markets can strengthen bank depositors' ability to monitor bank behaviour.

In the meantime, prior studies demonstrate that bank depositors can strongly react to bank risk. In the presence of market discipline, bank depositors require higher interest rates on their deposits or withdraw their deposits when banks take on more risk (Demirgüç-Kunt and Huizinga, 2004; Martinez-Peria and Schumkler, 2001). In this paper, our investigation regarding market discipline differs from previous studies, since we assess bank depositors' reaction to bank risk indirectly via bank market structure. As the market structure of banks clearly affects bank risk, we expect that bank depositors' reaction to bank risk is also dependent on bank market structure.

On the whole, this paper provides several policy implications in order to enhance both financial intermediation and bank stability. Specifically, what type of bank market structure will strengthen both financial intermediation and bank stability? Could bank regulators rely on the role played by depositors to discipline banks' behavior instead of preserving a banking market structure that precludes financial intermediation? We believe that these questions are of particular interest in both academic and policy circles to ensure better bank resilience and macroeconomic performance. 


\section{Data, variables and methodology}

\subsection{Data}

An unbalanced panel of annual bank-level data are retrieved from BankScope Fitch IBCA. Our dataset initially consists of 686 commercial banks from 12 countries in Asia Pacific from 1994 to 2009. These countries include China (103), Hong Kong (68), India (84), Indonesia (108), Malaysia (63), Sri Lanka (14), South Korea (50), Taiwan (50), Thailand (40), Pakistan (34), Philippines (39), and Vietnam (33)². Moreover, country-specific data are also taken from various sources. These include the International Financial Statistics (IFS) established by the International Monetary Fund, the World Bank Financial Structure Dataset established by Beck and Demirgüç-Kunt (2009), as well as the economic freedom index at the country level coming from Heritage Foundation. All country-specific data other than the ratio of stock market capitalization to gross domestic product (STOCK) and the economic freedom index (ECOFREE) come from the IFS. Meanwhile, STOCK and ECOFREE come from Beck and Demirgüç-Kunt (2009) and Heritage Foundation, respectively.

\subsection{Variables}

\subsubsection{Dependent variables}

Bank loan growth is used to assess financial intermediation. Let $i$ and $t$ represent bank index and time index, respectively. We define bank loan growth as follows:

$$
\operatorname{DLOAN}_{i, t}=\left(L_{i, t}-L_{i, t-1}\right) / 0.5\left(T A_{i, t}+T A_{i, t-1}\right)
$$

$L$ is banks' total loans in million US dollar, while TA is banks' total assets in million US dollar. Moreover, for robustness considerations, we also consider another measure of bank loan growth. Specifically, we use the annual growth rate of total loans (LOANG).

In the meantime, we use credit risk and income volatility measures to assess bank stability. Credit risk is defined as the ratio of loan loss provisions to total loans $(L L P)$, while income volatility is the standard deviation of the return on assets computed from a three-period rolling window (SDROA). In other words, the standard deviation of return on assets at time $t$ is calculated based on the return on assets from time $t$ to $t-2$.

\footnotetext{
${ }^{2}$ The number of banks in each country is shown in parentheses.
} 
Finally, in order to measure how bank depositors react to bank risk, we use the following measure where $D$ is bank total deposits in million US dollar.

$$
D D E P O_{i, t}=\left(D_{i, t}-D_{i, t-1}\right) / 0.5\left(T A_{i, t}+T A_{i, t-1}\right)
$$

Alternatively, we consider the annual growth rate of total deposits (DEPOG) as in Martinez-Peria and Schmukler (2001).

\subsubsection{Bank market structure}

In order to assess bank market structure, we construct the Lerner index derived from the industrial organization approach. Indeed, there are various methods to assess the degree of competition in banking markets. As a straightforward method, previous papers use the Herfindahl index (e.g. Berger et al, 2009; Schaeck and Cihak, 2009; Behr et al, 2010), or bank concentration ratios as in Uhde and Heimeshoff (2009). However, these two indicators are rather crude measures which do not appropriately infer the degree of competition among banks, since they do not take into account different characteristics of banks, such as asset size, business type, ownership type, and so on (Beck, 2008).

To better infer the degree of bank competition, Uchida and Tsutsui (2005) is the first to modify the non-structural measure of competition derived from Bresnahan (1982) and applied to Japanese banks. The merit of this measure is that it does neither require any assumption on the equilibrium of the banking market as in Panzar and Rosse (1987), nor the market structure of each bank which can be different across banks, even for similar types of banks. Using a panel data methodology, Uchida and Tsutsui's (2005) method can again capture the degree of bank competition over time.

The aggregate index of bank market power derived by Uchida and Tsutsui (2005) is already used in previous studies related to Asian banks. These include Soedarmono et al. (2011) and Soedarmono et al. (2013). Specifically, the degree of bank competition is computed using the system of equations as follows: 


$$
\begin{aligned}
\ln C_{i t}= & b_{0}+b_{1} \overline{\ln q_{i t}}+\frac{1}{2} b_{2}\left(\overline{\ln q_{i t}}\right)^{2}+b_{3} \overline{\ln d_{i t}}+\frac{1}{2} b_{4}\left(\overline{\ln d_{i t}}\right)^{2}+b_{5} \overline{\ln w_{i t}}+\frac{1}{2} b_{6}\left(\overline{\ln w_{i t}}\right)^{2} \\
& +b_{7}\left(\overline{\ln q_{i t}}\right)\left(\overline{\ln w_{i t}}\right)+b_{8}\left(\overline{\ln q_{i t}}\right)\left(\overline{\ln d_{i t}}\right)+b_{9}\left(\overline{\ln d_{i t}}\right)\left(\overline{\ln w_{i t}}\right)+e_{i t}^{C} \\
R_{i t}= & \frac{\theta_{t}}{\eta_{t}} R_{i t}+r_{i t} q_{i t}+c_{i t}\left(b_{1}+b_{2}\left(\overline{\ln q_{i t}}\right)+b_{7}\left(\overline{\ln w_{i t}}\right)+b_{8}\left(\overline{\ln d_{i t}}\right)\right) \\
& +C_{i t} \frac{q_{i t}}{d_{i t}}\left(b_{3}+b_{4}\left(\overline{\ln d_{i t}}\right)+b_{8}\left(\overline{\ln q_{i t}}\right)+b_{9}\left(\overline{\ln w_{i t}}\right)\right)+e_{i t}^{S} \\
\ln p_{i t}= & g_{0}-(1 / \eta) \ln q_{i t}+g_{1} \ln G D P G_{t}+g_{2} \ln S_{T O C K_{t}}+g_{2} \ln I R_{t}+g_{3} \ln T A_{i t}+e_{i t}^{D}
\end{aligned}
$$

Each variable with bars represents a deviation from its cross-sectional mean in each time period. Bank competition for each year is represented by $\theta_{t} \in[0,1]$ depicting the conjectural variations of elasticity of total banking industry outputs with respect to the output of bank $i$. In the case of perfect competition, $\theta_{t}=0$; under pure monopoly, $\theta_{t}=1$; and finally, $\theta_{t}<0$ implies pricing below marginal cost.

Moreover, $C_{i t}$ is defined by total expenses, $q_{i t}$ by total earning assets, $d_{i t}$ by total deposits and short-term funding, $w_{i t}$ by the ratio of operating expenses to total assets, $R_{i t}$ by total revenue, $r_{i t}$ by the ratio of interest expenses to total deposits, $p_{i t}$ by the ratio of total revenue to total earning assets. $G D P G_{t}, S T O C K_{t}, I R_{t}$ and $T A_{i t}$ are factors that affect the demand for loans, defined as the growth of real gross domestic product $(G D P)$, the ratio of stock market capitalization to $G D P$, the short-term interest rate, and bank total assets, respectively.

To estimate System (1), country-level estimations are conducted and we use the Seemingly Unrelated Regression (SUR) method, while $\theta_{t}$ is estimated by annual time dummy variables and $\eta$ by bi-annual time dummy variables (every two years), since $\eta$ values are linearly dependent on the time-specific variables (GDPG, STOCK and IR). In the subsequent analyses, $\theta_{t}$ denotes the Lerner index of the banking industry in each country over time (LERNER). 


\subsubsection{Control variables}

Several bank-specific control variables are incorporated in this study. First, bank size (SIZE) measured by the logarithm of banks' total assets is considered as one of the control variables because larger bank size tends to exacerbate bank risk taking (Mishkin, 2006) and to some extents, larger banks are subject to greater market discipline (Demirgüç-Kunt and Huizinga, 2011). Bank size is also a determinant of bank loan growth as in Foos et al (2010).

Second, we incorporate the ratio of total deposits to total assets (DEPO) as a control variable which directly affects deposit growth (DDEPO or DEPOG). Bank deposits are also the source of withdrawal risk and thus, DEPO is expected to have a significant relationship with bank risk. Bank deposits can also have an impact on loan growth because of the nature of intermediation activities in banking (deposits funded loans).

Third, we consider the banks' total capital adequacy ratio $(C A R)$, since bank capital ratios admittedly affect lending behaviour which may lead to "capital crunch" problems. The capital adequacy ratio may also affect risk and in turn affect market discipline through its influence on bank risk.

Another source of loan growth and bank risk is the extent to which banks engage in non-interest income activities. In particular, banks engaging in fee and commissionbased income can underprice loans and hence, granting loans at a lower cost in order to sell other fee-based products to their customers. This in turn fosters loan growth, but underestimated credit risk may erode bank stability. To account for non-interest income activities, we incorporate the ratio of non-interest income to total revenue $(N N I)$ as a control variable.

Aside from bank-specific factors, we also consider country-specific factors as control variables. We consider the inflation rate $(I N F)$, where higher inflation rate can increase the bank lending rate which deepens adverse selection problems and might increase bank instability. Meanwhile, bank loan growth and risk are also strongly correlated with economic growth. As economic growth increases, banks tend to foster loan activities and underestimate risk which can result in higher bank fragility. However, economic growth can also neutralize bank moral hazard and risk, particularly when 
economic growth contributes to real sector profitability and bank stability (Soedarmono et al, 2011). To account for economic growth, we use the growth rate of real per capita gross domestic product (GDPG).

In the next turn, we also consider the degree of economic freedoms (ECOFREE) and the foreign exchange reserves growth rate $(F O R E X G)$ to control for institutional development and macroeconomic stability. Higher institutional development indeed affects bank risk and banks' incentives to grant loans (Houston et al, 2011; Fernandez et al, 2010), while Mohanty and Turner (2006) argue that foreign exchange reserves may affect bank risk exposure because banks are sensitive to foreign exchange fluctuations.

\subsection{Methodology}

To accurately conduct our empirical investigation, we eliminate values which are higher than 1 and smaller than 0 for DEPO, CAR and NNI. Table 1 presents the descriptive statistics of all the "clean" variables used in this study.

[Insert Table 1 here]

In terms of econometric methodology, we use a dynamic panel data model. In reality, loan growth, risk and deposit growth in banking vary over time, while their current values at time $t$ are more likely to be dependent on their value at time $t-1$. Based on the nature of these dependent variables, the use of dynamic panel data methodology is relevant. Dynamic panel data models that account for the one year-lagged value of dependent variable as control variable, and that are able to endogenize several explanatory variables, are again appropriate to cope with reverse causality problems which may occur between dependent and explanatory variables. Dynamic panel data models are also appropriate to analyze both the short-run and long-run effects of explanatory variables on dependent variables.

In this study, our explanatory variable of interest is the degree of bank competition (LERNER). Given the possibility that banks do not immediately respond to changes in market structure, it is also worth examining whether bank market structure after a one year time lag or $\operatorname{LERNER(-1)}$ has an impact on dependent variables. 
Furthermore, we use the two-step Generalized Method of Moments (GMM) estimations following Arellano and Bover (1995) and Blundell and Bond (1998). This method is also referred to as the system GMM.

The System GMM is essentially an extension of the standard GMM developed by Arellano and Bond (1991). Arellano and Bond (1991) only consider the first difference of each variable in the regressions, while the lagged levels of explanatory variables are used as instruments. The use of the lagged levels as instruments may be inappropriate, particularly when variables are close to a random walk. To overcome this shortcoming, Arellano and Bover (1995) and Blundell and Bond (1998) develop the system GMM to improve the standard GMM by introducing the levels equation to produce a system of two equations consisting of the levels equation itself and the first-differenced equation. Hence, lagged differences of the explanatory and dependent variables can be valid instruments for the levels equation. To this end, Baltagi (2005) proves that the System GMM produces more efficient and precise estimates than the standard GMM.

Likewise, we introduce several endogenous variables in our dynamic panel data models. In all dynamic panel data models we run, we consider LERNER and LERNER(-1) as endogenous variables because both variables are estimated using the SUR method based on a system of three equations as shown in System (1). Hence, LERNER and LERNER(1) can contain measurement error and thus, need to be instrumented. We also consider $C A R$ as an endogenous variable, because bank capital management is dependent on banks' managerial discretion, as well as bank-specific and country-specific characteristics including bank size, ownership type, bank market structure, business cycle, and so on. Finally, we also endogenize $G D P G$, since the real per capita income growth is admittedly dependent on various factors, including bank market structure (Fernandez et al, 2010). Endogenizing GDPG can thus overcome simultaneity bias in which $G D P G$ can be influenced by other explanatory variables, including $L E R N E R$.

Given that our models contains an autoregressive variable, we then use the orthogonal deviations transformation of instrumental variables in order to take crosssection fixed effects into account. Considering bank-level fixed effects is an important dimension because our bank sample is heterogeneous and comes from different countries with different macroeconomic, institution and regulatory environments. We further 
include time dummies in our models to account for time fixed-effects. Yet, we also take into account Windmeijer's (2005) finite sample correction to ensure that our estimates are robust. Finally, we verify the validity of our dynamic panel data models using $A R(2)$ test and Hansen-J test. The GMM model is valid when AR (2) and Hansen-J test are both not significant, which respectively show that there is no second order serial correlation among errors of first-differenced equation, and that our identifying restrictions are valid.

\section{Empirical results}

\subsection{Bank market structure and loan growth}

When banks operate in a more competitive market, they tend to boost loans by setting lower loan prices to attract new borrowers (Ogura, 2006). Prior literature also suggests that higher degree of bank competition boosts small businesses development, as borrowing costs decline (Degryse and Ongena, 2005; Cetorelli and Gamberra, 2001). Building on such findings, we focus our investigation on the impact of bank market structure on loan growth as a proxy of financial intermediation.

As shown in Table 2, we highlight that banks in less competitive markets tend to reduce loan growth. In other words, our findings are consistent with the nexus between LERNER and bank loan growth (DLOAN or LOANG). We further notice that DLOAN and $L O A N G$ equations are both valid, as both $A R$ (2) test and Hansen-J test are not significant.

[Insert Table 2 here]

Several insights can be drawn from these findings. Banks in less competitive markets tend to have higher market power which enables them to increase their lending rates. However, Banks in less competitive markets might also be more prudent than those in competitive markets, and therefore higher credit risk might be priced appropriately which unfortunately leads to lower loan growth.

Moreover, in the presence of asymmetric information in loan markets, entrepreneurs who obtain loans can respond to higher loan pricing by running riskier projects to offset higher lending rates. Entrepreneurs' moral hazard can therefore 
exacerbate bank riskiness through risk-shifting mechanisms (Stiglitz and Weiss (1981)). On the contrary, in the absence of asymmetric information, bank riskiness will decline with higher LERNER, as long as banks in less competitive markets do not underestimate risk and set up lending rates appropriately, albeit reducing loan growth afterward. In the following section, we investigate the impact of $L E R N E R$ on bank riskiness in order to verify whether the relation between LERNER and bank loan growth (DLOAN or LOANG) is presumably characterized by the presence of asymmetric information.

\subsection{Bank market structure and risk}

In Table 2, we document our empirical results on the nexus between LERNER and bank risk measured by credit risk ( $L L P)$ and income volatility (SDROA). We find that higher LERNER is associated with higher LLP and SDROA, suggesting that banks in less competitive markets tend to have higher credit risk and income volatility. The positive link between $L E R N E R$ and bank riskiness (LLP and SDROA) is also unaltered when we consider the impact of LERNER at time $t-1$ on bank riskiness at time $t$, although such a positive link is tempered. Hence, higher LERNER clearly results in higher bank riskiness. Moreover, both $L L P$ and SDROA equations in Table 2 are valid because $A R(2)$ test and Hansen-J test are not significant. This result remains consistent with Soedarmono et al (2011 \& 2013), although in their study they apply a static panel data model using both fixed effect and two-stage least squares methods.

Combining the results regarding the competition-growth nexus, as well as the competition-stability nexus, we show that although banks in less competitive markets reduce loan growth, such a reduction is not sufficient to improve their stability. Hence, as mentioned earlier, asymmetric information problems are more likely to exist exacerbating entrepreneurs' moral hazard that in turn might increase the riskiness of banks in less competitive markets.

\subsection{Bank market structure and deposit growth}

Since higher market power in banking leads to lower loan growth but higher instability in Asian banks, it is worth examining whether such instability can be mitigated by market discipline. In this section, we are particularly interested in the role played by 
bank depositors in facing higher bank riskiness. Market discipline is indeed of particular interest for bank regulators and it has been further emphasized in the new Basel accords.

From Table 2, we observe that the link between LERNER and deposit growth (DDEPO and DEPOG) is negative and significant. This indicates that banks in less competitive markets experience lower deposit growth. Given that banks in less competitive markets (higher LERNER) tend to exhibit higher credit risk and income volatility as discussed in the previous section, our results show that bank depositors are indeed sensitive to bank risk along with an increase in market power in banking. Overall, our GMM models for DDEPO and DEPOG equations are valid because $A R(2)$ test and Hansen-J test are both insignificant.

\subsection{Robustness checks}

\subsubsection{Alternative model specifications}

For robustness $^{3}$, we now provide several sensitivity analyses. First, we do not consider GDPG and $C A R$ as endogenous variables in the estimations using a dynamic panel data methodology. Using this specification, the impact of LERNER on loan growth, risk and deposit growth in banking remains unaltered. This new specification also remains valid because both $A R(2)$ test and Hansen-J test are not significant. Second, we eliminate time dummies from our dynamic panel data models and again, this consideration does not change our findings.

\subsubsection{Static panel data methodology}

To further ensure the robustness of the impact of market power in banking on bank loan growth, risk and deposit growth, we re-estimate the link using a static panel model by taking into account individual and time-fixed effects. Table 3 presents our empirical results using the panel fixed effects regressions. Our previous findings remain consistent and robust.

[Insert Table 3 here]

\footnotetext{
${ }^{3}$ The results are not presented in the paper, but are available upon request to the authors
} 


\subsection{Bank market structure and loan pricing: an additional analysis}

We also perform an additional analysis to highlight whether a decline in bank loan growth and an increase in risk along with higher market power in banking are indeed due to the fact that banks in less competitive markets set higher loan pricing. Hence, we now examine how market power in banking affects bank loan pricing.

In order to assess bank loan pricing, we use the ratio of net interest income to total earning assets or net interest margin (NIM). Alternatively, we also use the ratio of net interest income to total assets (NIMTA). Initially, NIM and NIMTA are cleaned to ensure that they neither contain outliers nor exhibit a skewed distribution. Specifically, we impose a restriction to NIM and NIMTA by eliminating both their $2.5 \%$ lowest values and $2.5 \%$ highest values. Table 4 presents the empirical results using the two-step GMM dynamic panel data model following Blundell and Bond (1998).

\section{[Insert Table 4 here]}

From Table 4, we document that higher LERNER is significantly associated with higher

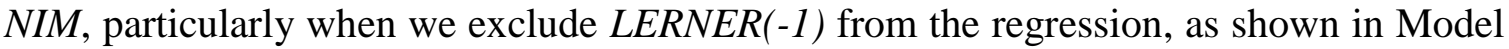
2. In fact, incorporating $\operatorname{LERNER(-1)}$ in the regression does not alter the relationship sign between LERNER and NIM, albeit not statistically significant, as shown in Model 1 (Table 4).

Our model that specifically uses NIM as the dependent variable is valid because $A R(2)$ tests are not rejected. Meanwhile, Hansen-J tests are not significant and hence, the validity of our instrumental variables remains ensured at least at the 5\% level. However, when we use NIMTA as an alternative measure of net interest margin, the results are less robust than those when NIM is used as a proxy of net interest margin. Although we still find a positive relationship between LERNER and NIMTA.

These findings indicate that banks in less competitive markets tend to charge higher interest rates on loans which increases net interest margin. By extension, as discussed from Section 4.1 to 4.2 , such a behavior leads to a decline in loan growth and an increase in bank risk because of the presence of entrepreneurial moral hazard in loan markets. 


\section{Conclusion}

This paper aims to highlight the implication of bank market structure on financial intermediation and bank riskiness. Our findings strongly emphasize that market power in banking is negatively related to bank loan growth as a proxy of financial intermediation, and is positively associated with bank instability measured by credit risk and income volatility. Banks in less competitive markets are indeed more unstable and less beneficial than those in competitive markets in strengthening financial intermediation. In addition to that, this study further highlights the role of market discipline exerted by bank depositors. As market power in banking results in higher instability, bank depositors in less competitive markets tend to deposit lower amounts. Nevertheless, there are also other factors affecting bank market discipline in the case of Asian banks.

\section{References}

Adams, C., 2008. Emerging East Asian banking system: Ten years after the 1997/98 crisis. ADB Working Paper Series on Regional Economic Integration No.16

Arellano, M., Bover, O., 1995. Another look at the instrumental variable estimation of error-component models. Journal of Econometrics 68, 29-51.

Arellano, M., Bond, S., 1991. Some tests of specification for panel data: Monte Carlo evidence and an application to employment equations. Reviews of Economic Studies 58, 277-297.

Ariss, R.T., 2010. On the implications of market power in banking: Evidence from developing coutnries. Journal of Banking and Finance 34 (4), 765-775

Baltagi, B.H., 2005. Econometric Analysis of Panel Data, third ed. John Wiley \& Sons Ltd., Chichester.

Beck, T., Demirgüç-Kunt, A., 2009. Financial institutions and markets across countries and over time: Data and analysis. Working paper series, 4943, World Bank, Washington, DC

Beck T., 2008. Bank competition and financial stability: friends or foes? Working paper series, 4656, World Bank, Washington, DC

Beck, T., Dermirguc-Kunt, A., Levine, R., 2006. Bank concentration, competition and 
crises: First results. Journal of Banking and Finance 30, 1581-1603

Beck, T., Demirgüç-Kunt, A., Maksimovic, V., 2004. Bank competition and access to finance: International evidence. Journal of Money, Credit and Banking 36, 627-648

Behr, P., Schmidt, R.H., Xie, R., 2010. Market structure, capital regulation, and bank risk taking. Journal of Financial Services Research 37(2-3), 131-158

Berger, A.N., Klapper, L.F., Ariss, R.T., 2009. Bank competition and financial stability. Journal of Financial Services Research 35, 99-118

Berlin, M., Mester, L.J., 1998. On the Profitability and Cost of Relationship Lending. Journal of Banking and Finance 22, 873-897

Bernanke, B. S., Lown, C. S., 1991. Credit crunch. Brookings Papers on Economic Activity 2, 205-47.

Black, S.E., Strahan, P., 2002. Entrepreneurship and bank credit availability. Journal of Finance 57(6), 2807-2833

Blundell, R., Bond, S., 1998. Initial conditions and moment restrictions in dynamic panel data models. Journal of Econometrics 87, 115-143.

Bouvatier, V., Lepetit, L., 2008. Banks' procyclical behaviour: does provisioning matter? Journal of International Financial Markets, Institutions and Money 18, 513-526.

Boyd, J.H., De Nicolo, G., 2005. The theory of bank risk taking and competition revisited. Journal of Finance 60, 1329-1343

Boyd, J.H., De Nicolo, G., Jalal, A.M., 2006. Bank risk-taking and competition revisited: new theory and new evidence. Working paper series 06/297, International Monetary Fund, Washington, DC

Bresnahan, T.F. 1982. The oligopoly solution concept is identified. Economics Letters $10,87-92$

Brissimis, S.N., Delis, M.D., Papanikolaou, N.I., 2008. Exploring the nexus between banking sector reform and performance: Evidence from newly acceded EU countries. Journal of Banking and Finance 32, 2674-2683

Cetorelli, N., Gambera, M., 2001. Banking market structure, financial dependence and growth: International evidence from industry data. Journal of Finance 56, 617-648

Degryse, H., Ongena, S., 2005. Distance, lending relationships and competition. Journal of Finance 60, 231-266 
Demirgüç-Kunt, A., Huizinga, H., 2011. Do we need large banks? Evidence on performance, strategy and market discipline. European Banking Center Discussion Paper No.005.

Demirgüç-Kunt, A., Huizinga, H., 2004. Market discipline and deposit insurance. Journal of Monetary Economics 51, 375-399.

Demsetz, R.S., Saidenberg, M.R., Strahan, P.E., 1996. Banks with something to lose: the disciplinary role of franchise value. Economic Policy Review, 1-14

Domanski, D. 2005. Foreign banks in emerging economies: Changing players changing issues. BIS Quarterly Review, 69-81

Fernandez, A.I., González, F., Suarez, N., 2010. How institutions and regulation shape the influence of bank concentration on economic growth: International evidence. International Review of Law and Economics 30 (1), 28-36

Foos, D., Norden, L., Weber, M., 2010. Loan growth and riskiness of banks. Journal of Banking and Finance 34(12), 2929-2940.

Goddard, J., Liu, H., Molyneux, P., Wilson, J.O.S., 2011. The persistence of bank profit. Journal of Banking and Finance 35(11), 2881-2890.

Houston, J., Lin, C., Lin, P., Ma, Y., 2010. Creditor rights, information sharing, and bank risk taking. Journal of Financial Economics 96, 485-512.

Jeon, B.N., Olivero, M.P., Wu, J, 2011. Do foreign banks increase competition? Evidence from emerging Asian and Latin American banking markets. Journal of Banking and Finance 35, 856-875.

Keeley, M.C., 1990. Deposit insurance, risk and market power in banking. American Economic Review 80(5), 1183-1200

Levy-Yeyati, E., Micco, A. 2007. Concentration and foreign penetration in Latin American banking sectors: Impact on competition and risk. Journal of Banking and Finance 31, 1633-1647

Liu, H., Nguyen, L. and Molyneux, P. (2012) Competition and risk in South East Asian commercial banking. Applied Economics (forthcoming)

Martinez-Peria, M.S., Schmukler, S.L., 2001. Do depositors punish banks for bad behavior? Market discipline, deposit insurance and banking crises. Journal of Finance 56, 1029-1051.

Mishkin, F.S., 2006. How big a problem is too big to fail? Journal of Economic Literature 44, 988-1004. 
Moshirian, F., 2008. Financial services in an increasingly integrated global financial market. Journal of Banking and Finance 32 (11), 2288-2292

Ogura, Y., 2006. Learning from a rival bank and lending boom. Journal of Financial Intermediation 15, 535-555.

Panzar, J.C., Rosse, J.N., 1987. Testing for 'monopoly' equilibrium. Journal of Industrial Economics 35 (4), 443-456.

Peek, J., Rosengreen, E., 1995. The capital crunch: Neither a borrower nor a lender be. Journal of Money, Credit and Banking 27 (3), 625-638

Petersen, M. A., Rajan, R.G., 1994. The benefits of lending relationships: Evidence from small business data. Journal of Finance 49, 1367-1400.

Petersen, M. A., Rajan, R.G., 1995. The effect of credit market competition on lending relationships. Quarterly Journal of Economics 110, 407-443

Santoso, W. 2009. "Comment on "The Determinants of Cross-Border Merger and Acquisition Activity in the Banking Sector in Asia: Did the Asian Financial Crisis Change Them?" NBER Chapters, in: Financial Sector Development in the Pacific Rim, East Asia Seminar on Economics 18, 236-240 National Bureau of Economic Research

Schaeck, K, Cihak, M., Wolfe, S., 2009. Are More Competitive Banking Systems More Stable? Journal of Money, Credit and Banking 41(4), 711-734

Schaeck, K., Cihak, M., 2007. Banking competition and capital ratios. Working paper series, 07/216, International Monetary Fund, Washington, DC

Soedarmono, W., Machrouh, F., Tarazi, A., 2013. Bank competition, crisis and risk taking: Evidence from emerging markets in Asia. Journal of International Financial Markets, Institutions and Money 23, 196-221

Soedarmono, W., Machrouh, F., Tarazi, A., 2011. Bank market power, economic growth and financial stability: Evidence from Asian banks. Journal of Asian Economics 22(6), 460-470

Stiglitz, J., Weiss, A., 1981. Credit rationing with imperfect information. American Economic Review 71, 393-410

Uchida, H., Tsutsui, Y., 2005. Has competition in the Japanese banking sector improved? Journal of Banking and Finance 29, 419-439

Uhde, A., Heimeshoff, U., 2009. Consolidation in banking and financial stability in Europe: Empirical evidence. Journal of Banking and Finance 33, 1299-1311 
Williams, J., Nguyen, N., 2005. Financial liberalisation, crisis, and restructuring: A comparative study of bank performance and bank governance in South East Asia. Journal of Banking and Finance 29, 2119-2154

Windmeijer, F., 2005. A finite sample correction for the variance of linear efficient twostep GMM estimators. Journal of Econometrics 126, 25-51. 
Table 1. Descriptive statistics

\begin{tabular}{|c|c|c|c|c|c|}
\hline Variable & Definition & Mean & Std. Dev. & Min & Max \\
\hline \multicolumn{6}{|l|}{ Lerner } \\
\hline$Q$ & Total earning assets (million USD) & 12359.5 & 58044.65 & 0.126 & $1.44 \mathrm{E}+06$ \\
\hline$C$ & Total expenses (million USD) & 90240.113 & 529468.451 & 0.013 & 13897949 \\
\hline$D$ & Total deposits and short term funding (million USD) & 10535.445 & 54044.344 & 0.002 & 1431017.91 \\
\hline$R$ & Total revenue (million USD) & 75003.77 & 483640.2 & -2754.779 & 13897949 \\
\hline$W$ & Ratio of total operating expenses to total assets & 0.023908 & 0.024928 & $1.65 \mathrm{E}-04$ & 0.878493 \\
\hline$R$ & Ratio of interest expenses to total deposits & 0.10337 & 0.21097 & $1.52 \mathrm{E}-02$ & 8.5098 \\
\hline$P$ & Ratio of total revenue to total earning assets & 13.52625 & 32.28294 & -1.277457 & 675.2431 \\
\hline$I R$ & Annual short-term interest rate & 0.07779 & 0.07444 & 0.0007 & 0.6279 \\
\hline STOCK & Ratio of stock market capitalization to GDP & 0.89522 & 1.113848 & 0.00445 & 7.425013 \\
\hline \multicolumn{6}{|c|}{ Explanatory var. } \\
\hline LERNER & Lerner index (Lerner index) & 0.05340 & 0.52399 & -0.98699 & 1.92911 \\
\hline SIZE & Logarithm of bank total assets & 7.48835 & 2.01198 & -1.09961 & 14.36128 \\
\hline$D E P O$ & Ratio of total deposits to total assets & 0.72574 & 0.19381 & 0.00003 & 0.99655 \\
\hline$C A R$ & Total capital adequacy ratio & 0.16454 & 0.11255 & 0.00500 & 0.91500 \\
\hline$N N I$ & Ratio of non-net interest revenue to total revenue & 0.21961 & 0.20513 & 0.00007 & 0.99848 \\
\hline$I N F$ & Inflation rate & 0.06067 & 0.05901 & -0.03947 & 0.58020 \\
\hline$G D P G$ & Real per capita GDP growth rate & 0.05514 & 0.03393 & -0.13127 & 0.14195 \\
\hline ECOFREE & Economic freedom index & 0.61457 & 0.12189 & 0.38600 & 0.90500 \\
\hline FOREXG & Foreign exchange reserves growth rate & 0.20020 & 0.29048 & -0.68859 & 1.63632 \\
\hline \multicolumn{6}{|c|}{ Dependent var. } \\
\hline$D L O A N$ & Loan growth rate & 0.0512085 & 0.4326531 & -1.968385 & 1.496386 \\
\hline$L O A N G$ & Actual loan growth rate & 0.1759484 & 0.3409541 & -0.9954025 & 2.461539 \\
\hline$L L P$ & Ratio of loan loss provisions to total loans & 0.0193369 & 0.051427 & 0.0000136 & 0.9486932 \\
\hline SDROA & Standard deviation of ROA from time $t$ to $t-2$ & 0.011291 & 0.0371811 & $5.55 \mathrm{E}-06$ & 0.8463556 \\
\hline$D D E P O$ & Deposit growth rate & 0.09762 & 0.1944373 & -1.138423 & 1.569936 \\
\hline NIM & Ratio of net interest income to total earning assets & -0.0345608 & 0.1037 & -2.085 & 1.0714 \\
\hline NIMTA & Ratio of net interest income to total assets & -0.0276 & 0.0738 & -2.0508 & 1.0029 \\
\hline$D E P O G$ & Actual deposit growth rate & 0.184506 & 0.3865803 & -0.9979501 & 3.089286 \\
\hline
\end{tabular}


Table 2. Bank market structure, loan growth, risk and market discipline. All variable definitions follow Table 1. Models are estimated using the two-step Generalized Method of Moments (GMM) estimator following Blundell and Bond (1998) with Windmeijer's (2005) finite sample corrections, orthogonal deviations transformation of instruments and period dummies. Models are valid when AR(2) tests and Hansen-J tests are not rejected are not significant. $(* * *),(* *)$, and $(*)$ indicate significance at the $1 \%, 5 \%$ and $10 \%$ levels, respectively.

\begin{tabular}{|c|c|c|c|c|c|c|}
\hline & \multicolumn{2}{|c|}{ Loan Growth } & \multicolumn{2}{|c|}{ Risk } & \multicolumn{2}{|c|}{ Deposit Growth } \\
\hline & DLOAN & $L O A N G$ & $L L P$ & SDROA & DDEPO & $D E P O G$ \\
\hline \multicolumn{7}{|l|}{ Explanatory Variables } \\
\hline$D E P . V A R(-1)$ & $\begin{array}{l}-0.0672 * * \\
(0.029)\end{array}$ & $\begin{array}{l}0.1871 * * * \\
(0.029)\end{array}$ & $\begin{array}{l}0.1365 * * \\
(0.043)\end{array}$ & $\begin{array}{l}0.6519 * * * \\
(0.031)\end{array}$ & $\begin{array}{l}0.0438 \\
(0.034)\end{array}$ & $\begin{array}{l}0.0900 * * * \\
(0.034)\end{array}$ \\
\hline LERNER & $\begin{array}{l}-0.0402 * \\
(0.023)\end{array}$ & $\begin{array}{l}-0.0895^{* *} \\
(0.035)\end{array}$ & $\begin{array}{l}0.0241 * * * \\
(0.008)\end{array}$ & $\begin{array}{l}0.0016^{*} \\
(0.001)\end{array}$ & $\begin{array}{l}-0.0895 * * * \\
(0.025)\end{array}$ & $\begin{array}{l}-0.1244 * * * \\
(0.047)\end{array}$ \\
\hline $\operatorname{LERNER(-1)}$ & $\begin{array}{l}0.0240 \\
(0.021)\end{array}$ & $\begin{array}{l}0.0480 \\
(0.035)\end{array}$ & $\begin{array}{l}-0.0129 * * \\
(0.007)\end{array}$ & $\begin{array}{l}0.0006 \\
(0.001)\end{array}$ & $\begin{array}{l}0.0542 * * \\
(0.024)\end{array}$ & $\begin{array}{l}0.0941^{* *} \\
(0.045)\end{array}$ \\
\hline SIZE & $\begin{array}{l}-0.0036 \\
(0.003)\end{array}$ & $\begin{array}{l}0.0025 \\
(0.004)\end{array}$ & $\begin{array}{l}-0.0012 * * \\
(0.001)\end{array}$ & $\begin{array}{l}-0.0006 * * * \\
(0.000)\end{array}$ & $\begin{array}{l}-0.0000 \\
(0.002)\end{array}$ & $\begin{array}{l}-0.0059 \\
(0.005)\end{array}$ \\
\hline$D E P O$ & $\begin{array}{l}-0.0077 \\
(0.031)\end{array}$ & $\begin{array}{l}0.0378 \\
(0.044)\end{array}$ & $\begin{array}{l}0.0040 \\
(0.006)\end{array}$ & $\begin{array}{l}-0.0001 \\
(0.001)\end{array}$ & $\begin{array}{l}0.2412 * * * \\
(0.026)\end{array}$ & $\begin{array}{l}0.1380 * * \\
(0.055)\end{array}$ \\
\hline$C A R$ & $\begin{array}{l}-0.1107 \\
(0.074)\end{array}$ & $\begin{array}{l}-0.0067 \\
(0.120)\end{array}$ & $\begin{array}{l}0.0370 \\
(0.030)\end{array}$ & $\begin{array}{l}-0.0092 * * \\
(0.003)\end{array}$ & $\begin{array}{l}0.0532 \\
(0.074)\end{array}$ & $\begin{array}{l}-0.0134 \\
(0.153)\end{array}$ \\
\hline$N N I$ & $\begin{array}{l}-0.0038 \\
(0.035)\end{array}$ & $\begin{array}{l}0.0263 \\
(0.055)\end{array}$ & $\begin{array}{l}0.0133 * * \\
(0.007)\end{array}$ & $\begin{array}{l}0.0048 * * * \\
(0.001)\end{array}$ & $\begin{array}{l}0.0644 * * \\
(0.032)\end{array}$ & $\begin{array}{l}0.1015 \\
(0.070)\end{array}$ \\
\hline$I N F$ & $\begin{array}{l}0.1859 * * * \\
(0.054)\end{array}$ & $\begin{array}{l}0.4070 * * * \\
(0.102)\end{array}$ & $\begin{array}{l}-0.0205^{* *} \\
(0.010)\end{array}$ & $\begin{array}{l}-0.0033^{*} \\
(0.002)\end{array}$ & $\begin{array}{l}0.2231 * * * \\
(0.063)\end{array}$ & $\begin{array}{l}0.4385 * * * \\
(0.129)\end{array}$ \\
\hline$G D P G$ & $\begin{array}{l}0.5003 * * * \\
(0.123)\end{array}$ & $\begin{array}{l}0.8482 * * * \\
(0.203)\end{array}$ & $\begin{array}{l}-0.0907 * * * \\
(0.023)\end{array}$ & $\begin{array}{l}-0.0064 \\
(0.005)\end{array}$ & $\begin{array}{l}0.6102 * * * \\
(0.124)\end{array}$ & $\begin{array}{l}0.8357 * * * \\
(0.236)\end{array}$ \\
\hline ECOFREE & $\begin{array}{l}-0.1688 * * * \\
(0.000)\end{array}$ & $\begin{array}{l}-0.2812 * * * \\
(0.001)\end{array}$ & $\begin{array}{l}-0.0132 * * \\
(0.000)\end{array}$ & $\begin{array}{l}0.0026^{* *} \\
(0.000)\end{array}$ & $\begin{array}{l}-0.1135^{* * *} \\
(0.000)\end{array}$ & $\begin{array}{l}-0.1638^{* *} \\
(0.001)\end{array}$ \\
\hline FOREXG & $\begin{array}{l}0.0905 * * * \\
(0.017)\end{array}$ & $\begin{array}{l}0.1639 * * * \\
(0.027)\end{array}$ & $\begin{array}{l}0.0080 * * * \\
(0.003)\end{array}$ & $\begin{array}{l}-0.0002 \\
(0.001)\end{array}$ & $\begin{array}{l}0.1734 * * * \\
(0.017)\end{array}$ & $\begin{array}{l}0.2625 * * * \\
(0.034)\end{array}$ \\
\hline Observations & 3,268 & 3,000 & 2,609 & 3,023 & 3,037 & 3,006 \\
\hline Z-score for $A R(1)$ test. & $-4.36 * * *$ & $-6.72 * * *$ & $-2.78 * * *$ & $-5.42 * * *$ & $-7.24 * * *$ & $-5.15 * * *$ \\
\hline$Z$-score for $A R(2)$ test & -1.72 & 0.04 & 0.21 & -0.54 & -0.87 & -0.43 \\
\hline$p$-value for Hansen-J test & 0.516 & 0.871 & 0.963 & 0.795 & 0.842 & 0.867 \\
\hline Endogenous variables & $\operatorname{DLOAN}(-1)$ & $L O A N G(-1)$ & $\operatorname{LLP}(-1)$ & $\operatorname{SDROA}(-1)$ & $D D E P O(-1)$ & DEPOG $(-1)$ \\
\hline & LERNER & LERNER & LERNER & LERNER & LERNER & LERNER \\
\hline & $\operatorname{LERNER(-1)}$ & $\operatorname{LERNER(-1)}$ & $\operatorname{LERNER(-1)}$ & $\operatorname{LERNER(-1)}$ & $\operatorname{LERNER(-1)}$ & $\operatorname{LERNER}(-1)$ \\
\hline & $\begin{array}{l}C A R \\
G D P G\end{array}$ & $\begin{array}{l}C A R \\
G D P G\end{array}$ & $\begin{array}{l}C A R \\
G D P G\end{array}$ & $\begin{array}{l}C A R \\
G D P G\end{array}$ & $\begin{array}{l}C A R \\
G D P G\end{array}$ & $\begin{array}{l}C A R \\
G D P G\end{array}$ \\
\hline
\end{tabular}


Table 3. Bank market structure, loan growth, risk and market discipline. All variable definitions follow Table 1. Models are estimated using the fixed-effect panel regressions, accounting for both individual and time-fixed effects. $(* * *),(* *)$, and $(*)$ indicate significance at the $1 \%, 5 \%$ and $10 \%$ levels, respectively. Constants are included, but not reported.

\begin{tabular}{|c|c|c|c|c|c|c|}
\hline & \multicolumn{2}{|c|}{ Loan Growth } & \multicolumn{2}{|c|}{ Risk } & \multicolumn{2}{|c|}{ Deposit Growth } \\
\hline & DLOAN & $L O A N G$ & $L L P$ & SDROA & $D D E P O$ & $D E P O G$ \\
\hline \multicolumn{7}{|c|}{ Explanatory Variables } \\
\hline \multirow[t]{2}{*}{ LERNER } & $-0.1225 * * *$ & $-0.1202 * * *$ & $0.0049 *$ & -0.0036 & $-0.0776 * * *$ & $-0.1184 * * *$ \\
\hline & $(0.022)$ & $(0.026)$ & $(0.003)$ & $(0.001)$ & $(0.015)$ & $(0.029)$ \\
\hline \multirow[t]{2}{*}{ SIZE } & 0.0010 & $0.0259 * *$ & $-0.0053 * * *$ & $-0.0013 * * *$ & $0.0387 * * *$ & $0.0519 * * *$ \\
\hline & $(0.010)$ & $(0.011)$ & $(0.001)$ & $(0.000)$ & $(0.006)$ & $(0.012)$ \\
\hline \multirow[t]{2}{*}{$D E P O$} & -0.0467 & -0.0540 & $0.0117 *$ & $0.0065 * * *$ & $0.4567 * * *$ & $0.5511 * * *$ \\
\hline & $(0.051)$ & $(0.059)$ & $(0.006)$ & $(0.002)$ & $(0.033)$ & $(0.067)$ \\
\hline \multirow[t]{2}{*}{$C A R$} & $-0.1229 *$ & $-0.2560 * * *$ & $0.0315 * * *$ & -0.0016 & $0.0970 * *$ & 0.1020 \\
\hline & $(0.069)$ & $(0.081)$ & $(0.009)$ & $(0.002)$ & $(0.045)$ & $(0.090)$ \\
\hline \multirow[t]{2}{*}{$N N I$} & $0.0980 * * *$ & 0.0340 & $-0.0085^{* *}$ & -0.0014 & $0.1104 * * *$ & $0.1762 * * *$ \\
\hline & $(0.036)$ & $(0.041)$ & $(0.004)$ & $(0.001)$ & $(0.023)$ & $(0.046)$ \\
\hline \multirow[t]{2}{*}{$I N F$} & $0.2931 * * *$ & $0.3381 * * *$ & $-0.0193 *$ & -0.0046 & $0.2357 * * *$ & $0.3837 * * *$ \\
\hline & $(0.104)$ & $(0.116)$ & $(0.011)$ & $(0.003)$ & $(0.067)$ & $(0.131)$ \\
\hline \multirow[t]{2}{*}{$G D P G$} & $0.3235^{*}$ & $0.6730 * * *$ & $-0.0928 * * *$ & -0.0041 & $0.5069 * * *$ & $0.8964 * * *$ \\
\hline & $(0.177)$ & (0.199) & $(0.020)$ & $(0.006)$ & $(0.114)$ & $(0.223)$ \\
\hline \multirow[t]{2}{*}{ ECOFREE } & $0.0033 *$ & $-0.0044 * *$ & $0.0009 * * *$ & $0.0001 * *$ & -0.0006 & -0.0008 \\
\hline & $(0.002)$ & $(0.002)$ & $(0.000)$ & $(0.000)$ & $(0.001)$ & $(0.002)$ \\
\hline \multirow[t]{2}{*}{ FOREXG } & $0.0869 * * *$ & $0.1867 * * *$ & $0.0098 * * *$ & -0.0006 & $0.1878 * * *$ & $0.3038 * * *$ \\
\hline & $(0.021)$ & $(0.024)$ & $(0.002)$ & $(0.001)$ & $(0.014)$ & $(0.027)$ \\
\hline Observations & 3,532 & 3,342 & 3,087 & 3,353 & 3,371 & 3,351 \\
\hline R-square & 0.019 & 0.039 & 0.048 & 0.066 & 0.141 & 0.081 \\
\hline
\end{tabular}


Table 4. Bank market structure and net interest margin. All variable definitions follow Table 1. Models are estimated using the two-step Generalized Method of Moments (GMM) estimator following Blundell and Bond (1998) with Windmeijer's (2005) finite sample corrections, orthogonal deviations transformation of instruments and period dummies. Models are valid when AR(2) tests and Hansen-J tests are not rejected are not significant. $(* *),(* *)$, and $(*)$ indicate significance at the $1 \%, 5 \%$ and $10 \%$ levels, respectively.

\begin{tabular}{|c|c|c|c|c|}
\hline & \multicolumn{2}{|c|}{ Model 1} & Model 2 & \multirow[b]{2}{*}{ NIMTA } \\
\hline & NIM & NIMTA & NIM & \\
\hline \multicolumn{5}{|l|}{ Explanatory Variables } \\
\hline \multirow[t]{2}{*}{ DEP.VAR $(-1)$} & $0.111 * * *$ & $0.178 * * *$ & $0.112 * * *$ & $0.177 * * *$ \\
\hline & $(0.0408)$ & $(0.0408)$ & $(0.0402)$ & $(0.0388)$ \\
\hline \multirow[t]{2}{*}{ LERNER } & 0.00374 & $1.80 \mathrm{e}-05$ & $0.00319 * *$ & $0.00248 * *$ \\
\hline & $(0.00473)$ & $(0.00416)$ & $(0.00133)$ & $(0.00115)$ \\
\hline \multirow[t]{2}{*}{$\operatorname{LERNER(-1)}$} & -0.00206 & 0.00111 & & \\
\hline & $(0.00463)$ & $(0.00390)$ & & \\
\hline \multirow[t]{2}{*}{ SIZE } & 0.000587 & 0.000479 & 0.000397 & 0.000327 \\
\hline & $(0.000442)$ & $(0.000340)$ & $(0.000428)$ & $(0.000336)$ \\
\hline \multirow[t]{2}{*}{$D E P O$} & $0.00691 *$ & $0.00479 *$ & 0.00536 & 0.00361 \\
\hline & $(0.00390)$ & $(0.00281)$ & $(0.00382)$ & $(0.00277)$ \\
\hline \multirow[t]{2}{*}{$C A R$} & $0.0552 * * *$ & $0.0445 * * *$ & $0.0479 * * *$ & $0.0386 * * *$ \\
\hline & $(0.0112)$ & $(0.00974)$ & $(0.0109)$ & $(0.00931)$ \\
\hline \multirow[t]{2}{*}{$N N I$} & $-0.0313 * * *$ & $-0.0277 * * *$ & $-0.0330 * * *$ & $-0.0293 * * *$ \\
\hline & $(0.00379)$ & $(0.00352)$ & $(0.00371)$ & $(0.00335)$ \\
\hline \multirow[t]{2}{*}{$I N F$} & 0.00551 & 0.0101 & 0.000804 & 0.00651 \\
\hline & $(0.00821)$ & $(0.00668)$ & $(0.00830)$ & $(0.00660)$ \\
\hline \multirow[t]{2}{*}{$G D P G$} & $0.0437 * *$ & $0.0345 * *$ & $0.0440 * *$ & $0.0355 * *$ \\
\hline & $(0.0177)$ & $(0.0142)$ & $(0.0185)$ & $(0.0145)$ \\
\hline \multirow[t]{2}{*}{ ECOFREE } & $-0.0196 * * *$ & $-0.0149 * * *$ & $-0.0192 * * *$ & $-0.0146 * * *$ \\
\hline & $(0.00516)$ & $(0.00371)$ & $(0.00474)$ & $(0.0036)$ \\
\hline \multirow[t]{2}{*}{ FOREXG } & -0.00210 & -0.00123 & -0.00109 & -0.000273 \\
\hline & $(0.00211)$ & $(0.00158)$ & $(0.00187)$ & $(0.00145)$ \\
\hline Observations & 3285 & 3284 & 3378 & 3337 \\
\hline Z-score for $A R(1)$ test & $-3.40 * * *$ & $-3.59 * * *$ & $-3.38 * * *$ & $-3.61 * * *$ \\
\hline Z-score for $A R(2)$ test & -1.72 & $-2.09 * *$ & -1.78 & $-2.11 * *$ \\
\hline$p$-value for Hansen J-test & 0.621 & 0.657 & 0.519 & 0.605 \\
\hline \multirow{3}{*}{ Endogenous variables } & $\operatorname{NIM}(-1)$ & $\operatorname{NIMTA}(-1)$ & $\operatorname{NIM}(-1)$ & $\operatorname{NIMTA}(-1)$ \\
\hline & LERNER \& LERNER(-1) & LERNER \& LERNER(-1) & LERNER \& LERNER(-1) & LERNER \& LERNER(-1) \\
\hline & $C A R \& G D P G$ & $C A R \& G D P G$ & $C A R \& G D P G$ & $C A R \& G D P G$ \\
\hline
\end{tabular}


